\title{
Vietnam War and Landscape Dynamics Objective Identification by Iconographic Data in Thua Thien Hue Province
}

\author{
Amélie Robert-Charmeteau \\ Tours University, Tours, France
}

\begin{abstract}
During the Vietnam War, South-Vietnam underwent numerous herbicides spraying and bombing, which were conducted by the American army. These military activities aimed to defeat the enemy by destroying its environment; thus they were not without consequences on landscapes. As prime target of aerial attacks, the forests were particularly affected. The Vietnam War can thus be considered as a cause of forest loss but not the main one. Some assert that the areas affected by the military practices were forested before the war and the forest disappeared due to these ones; but did it correspond to the reality? To answer, to identify as objectively as possible the landscape dynamics, which occurred during the war, Thua Thien Hue province, particularly affected by the military practices, is taken as an example; its pre- (circa 1954) and post-war (1975) landscapes have to be reconstructed, basing on a priori unbiased data such as iconographic data. Aerial photographs are available for circa 1954 but the reconstruction can only be partial because some are missing and their processing is long. For 1975, another iconographic data is used, a satellite image; available, it has the advantage of covering the studied province and of requiring a shorter processing. The pre- and post-war landscapes thus known are then compared to identify wartime dynamics. This study demonstrates that some forests were destroyed but other sylvo-ecosystems progressed as well. Besides the military activities, the civilian practices were factors of these dynamics.
\end{abstract}

Keywords: Vietnam, war, landscape, herbicides, forest, remote sensing

\section{Introduction}

During the Vietnam War, the American army sprayed nearly 80 million liters of herbicides (Stellman et al., 2003, p. 323). The purpose was to destroy the crops of the enemies but also to destroy the forest under which they hid, to defeat them by destroying the environment. These chemical products were used at high concentration rate, that's why some authors describe the Vietnam War as a war against the environment: "The Vietnam War of 1961-1975 stands out as the archetypal example of warrelated environmental abuse" (Westing, 2002, p. 2). Agent Orange is the most famous herbicide, which was used during this conflict. These herbicides were sprayed especially by aircrafts, in the framework of the "Ranch hand" operation. They affected first South-Vietnam, above all Zone III and Zone I, which is located in Thua Thien Hue province (see Figure 1). This one was one of the main targets because of its location: it was in the south of the border between North and South-Vietnam and it was crossed by the Ho Chi Minh trail, which were followed by the Viet Cong, in the A Luoi valley. South-Vietnam also underwent numerous bombing during the Vietnam War and Thua Thien Hue appears as a preferred target for this military practice as well (see Figure 2).

Amélie Robert-Charmeteau, Geographer, Geography Department, Tours University. 


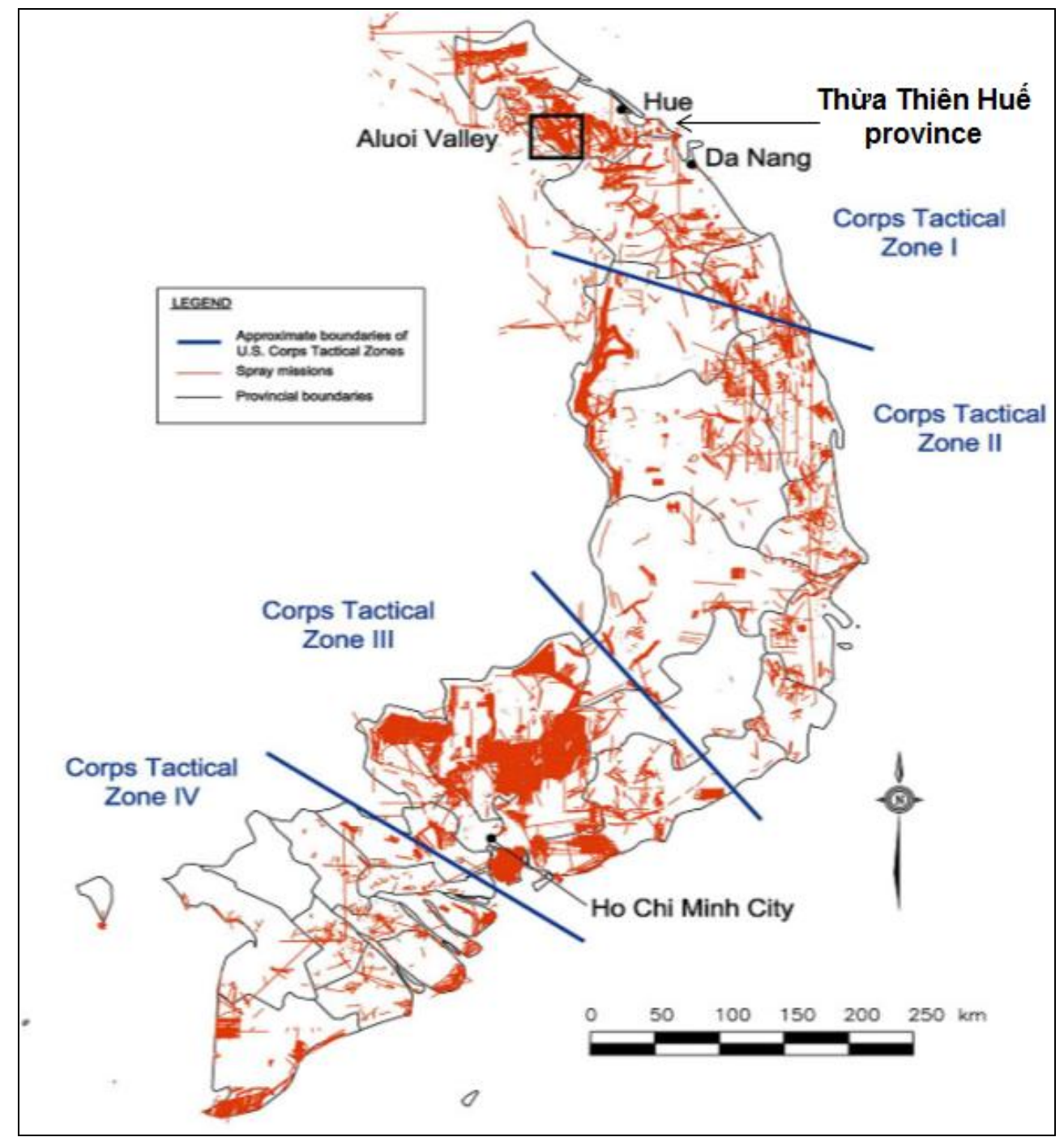

Figure 1. Aerial herbicides spray missions in southern Vietnam, 1965-1971.

Source: US Department of the Army, Hatfield Consultants LTD. Retrieved from http://www.hatfieldgroup.com/wp-content/uploads/VietNamHighlights/SprayLines.PDF

These military activities had consequences on landscapes. Following herbicides spraying, grass and shrub died. The contrast was visible between an affected area, which was bare, and a spared one, which was still covered by savanna (see Figure 3). Concerning forest areas, only the leaves color changed first (see Figure 4); then the leaves fell and the trees sometimes died. This consequence is controversial; some researchers, like Westing (1972), estimated that only 10\%-30\% of the over storey trees died following one spraying (p. 324); this percentage grew according to the number of spraying. After bombing, the landscapes of the affected area were scattered by craters, sometimes quite numerous. The American army also dropped incendiary bombs, like napalm bombs, which destroyed all around the target by fire.

The use of these arms had consequences on environment, on landscapes, especially on forest cover. That's why some authors claim that this war is one of the main causes of forest loss, at least in some places (Mekong Delta and Central Coast) (San \& Gilmour, 1999) ${ }^{1}$. But this assertion suffers from the lack of evidence-this

\footnotetext{
${ }^{1}$ From a survey conducted by the Ministry of Science Technology and Environment in 1998.
} 
point of view is defended by de Koninck (1999, p. 12), who opposes the bombarded forested area given by Collins to his assertion of "The destruction of most of the remaining forest" (Collins, 1990, pp. 158-159). It is based on official statistics, which can be biased, or on the postulate that the areas affected by the military practices were forested and that the forest disappeared due to these ones; but did it correspond to the reality? To overtake the controversies, to objectively identify the dynamics, which affected the South-Vietnamese landscapes during the war, the analysis was based on iconographic data.

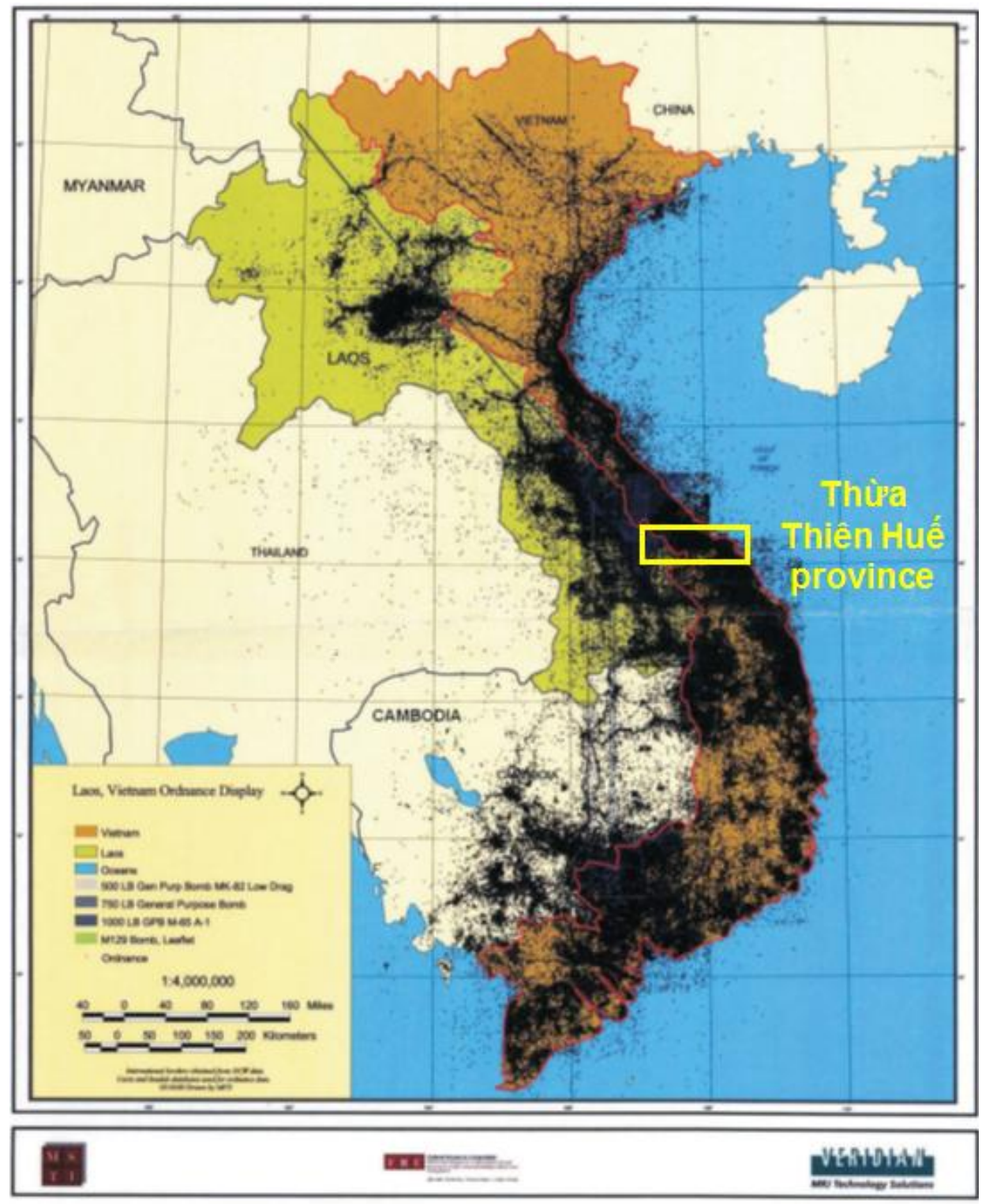

Figure 2. Aerial bombing in Southeast Asia during the Vietnam War.

Source: Retrieved from http://www.hatfieldgroup.com/wp-content/uploads/VietNamHighlights/bombs_vietnam.pdf.

\section{Materials and Method}

This work falls in the framework of a Ph.D. study (Robert, 2011), which aims to identify the contribution of the war in landscape dynamics, in deforestation process. The analysis was geo-historical and came under 
biogeography. Landscapes were reconstituted at key dates, which were chosen according to the societal periods, with some adaptations according to the available data; the studied periods thus differ from the societal periods (see Figure 5). These landscapes were compared in pairs in a regressive diachronic analysis, from today to the past, only a part of the study, which is focused on wartime dynamics, is considered.
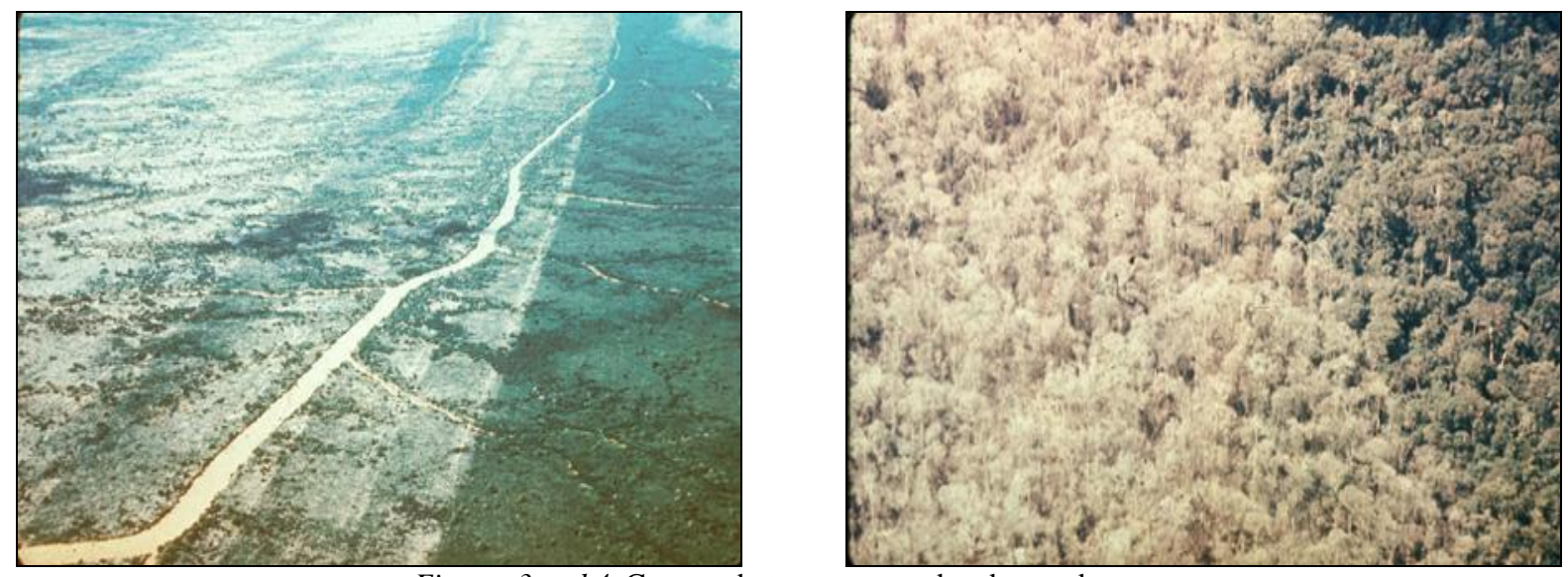

Figures 3 and 4. Contrast between sprayed and spared areas.

Source: Shots: VAS006793 and VAS006779, n. d., Ranch Hand Association Vietnam Collection, The Vietnam Archive, Texas Tech University: "Contrast".

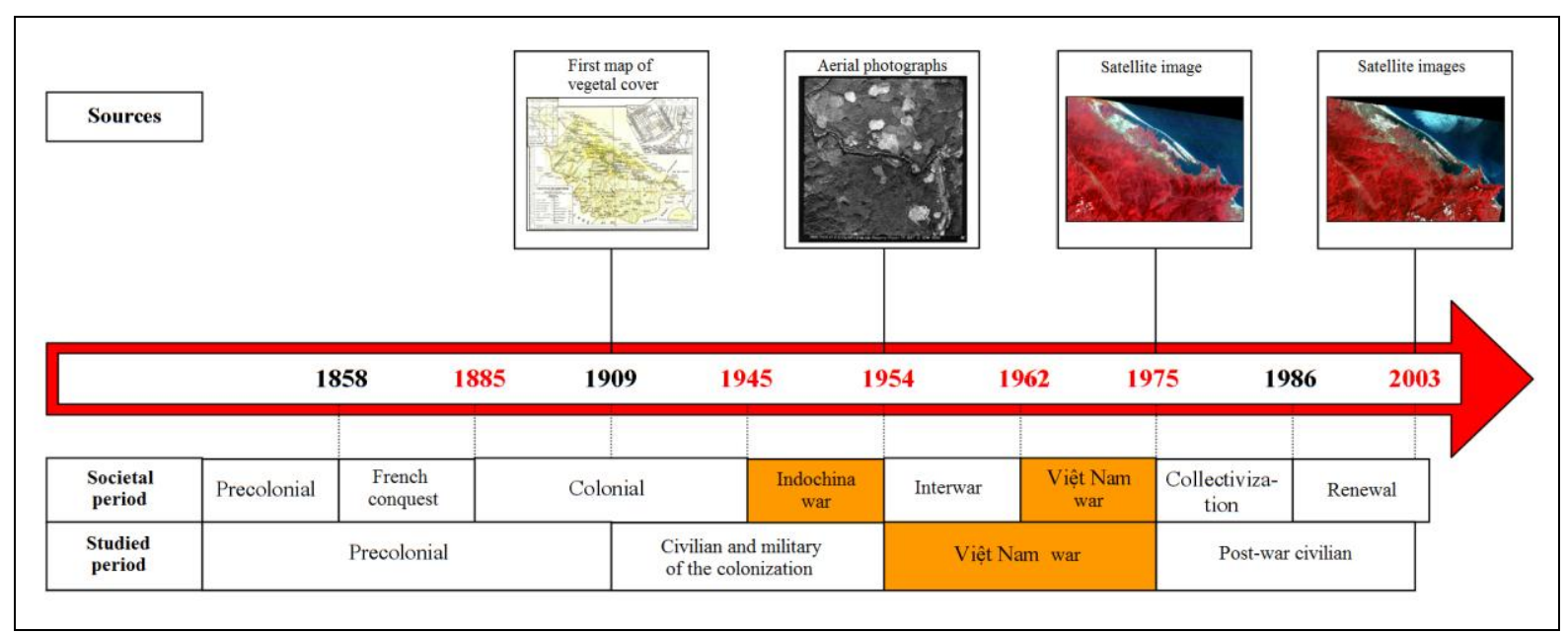

Figure 5. Chronological sequences: Sources and temporalities.

To reconstitute landscapes, the iconographic data were favored after comparison with other available data (Robert, 2011) because they are raw data and they are thus a priori unbiased. This feature was all the more important since the topic, on environmental consequences of the Vietnam War, is controversial. Such data had to be found for the pre- and post-war inventories because the purpose was to identify the wartime dynamics.

The knowledge of the landscapes before the war, around 1954, had to be based on aerial photographs, the only available raw data at this date. The advantage of these iconographic data is their high spatial resolution but they cover a short area and require a long processing; on the example taken for the Figure 6, 10 photographs were necessary to cover a five $\mathrm{km}$ transect. Furthermore, these aerial photographs are not available for the entire studied area, because they were taken by the French army according to military targets. For these reasons, 
the reconstruction of the pre-war landscapes was only partial.

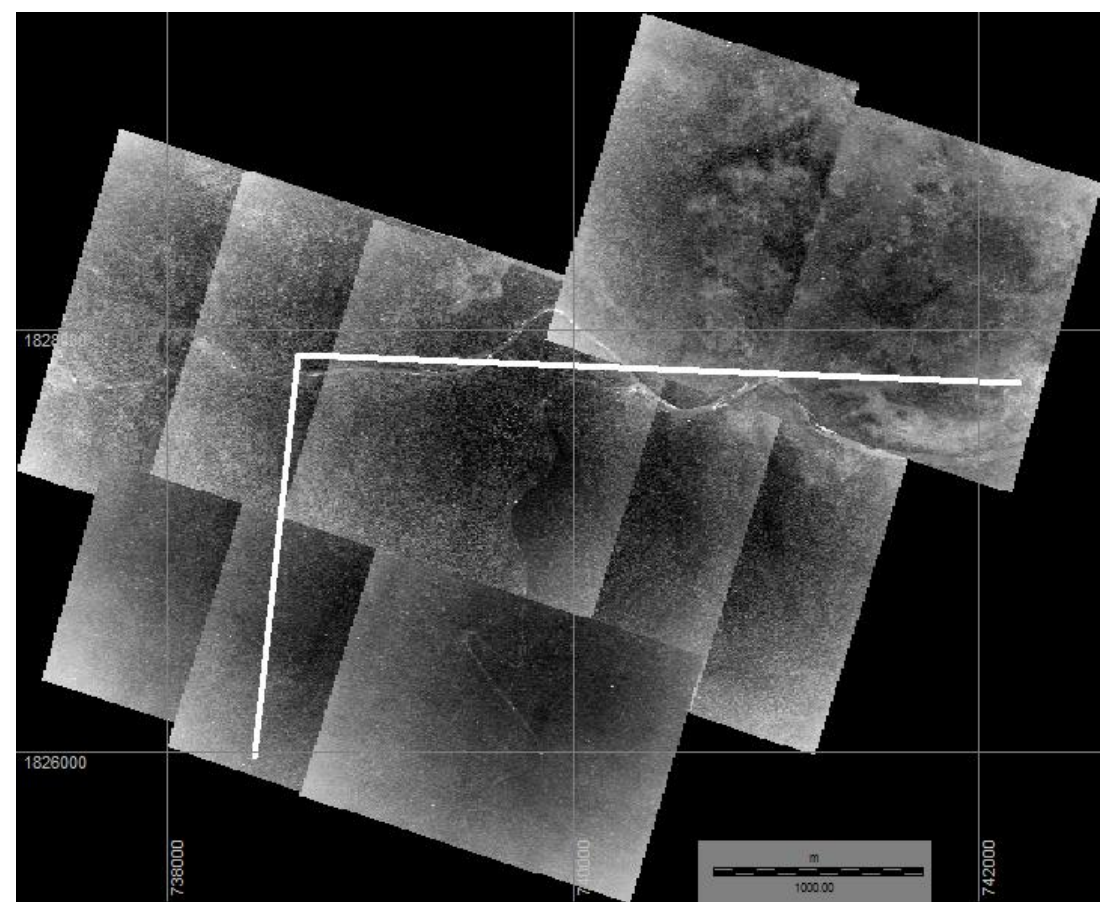

Figure 6. Aerial photographs: a high spatial resolution but a small covered area.

Source: Aerial photographs from Historical Service of Defense - Department of the Air Force (Service historique de la Défense - Département de l'Armée de l'Air, SHD-DAA): Plot 264, Mission TV 197 from May 16, 1953, Khe Tran transect (Georeferencing: UTM 48N/WGS 84).

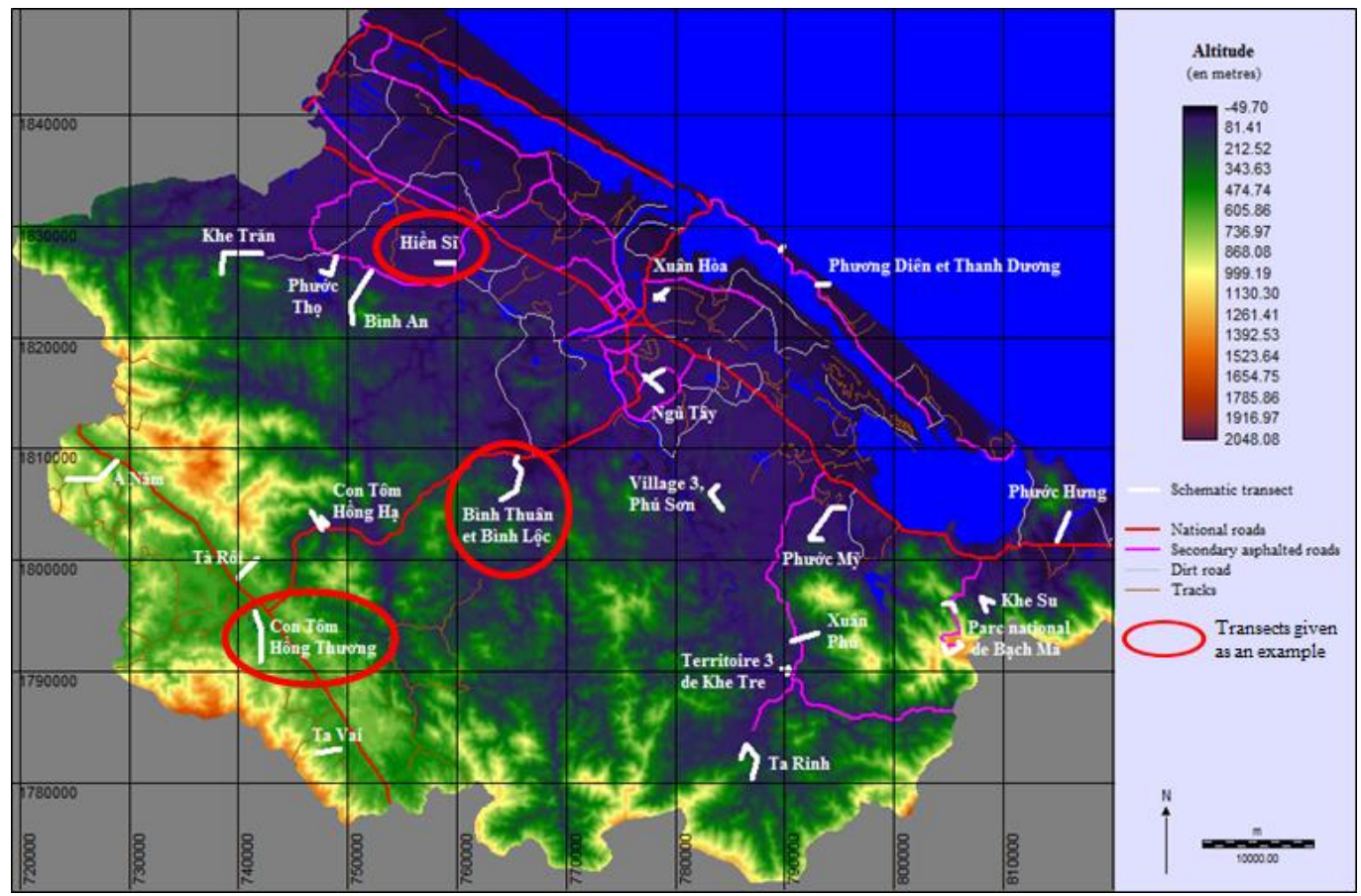

Figure 7. Three transects chosen in the three landscape units of the province.

Source: Robert, 2011 (Georeferencing: UTM 48N/WGS 84). 


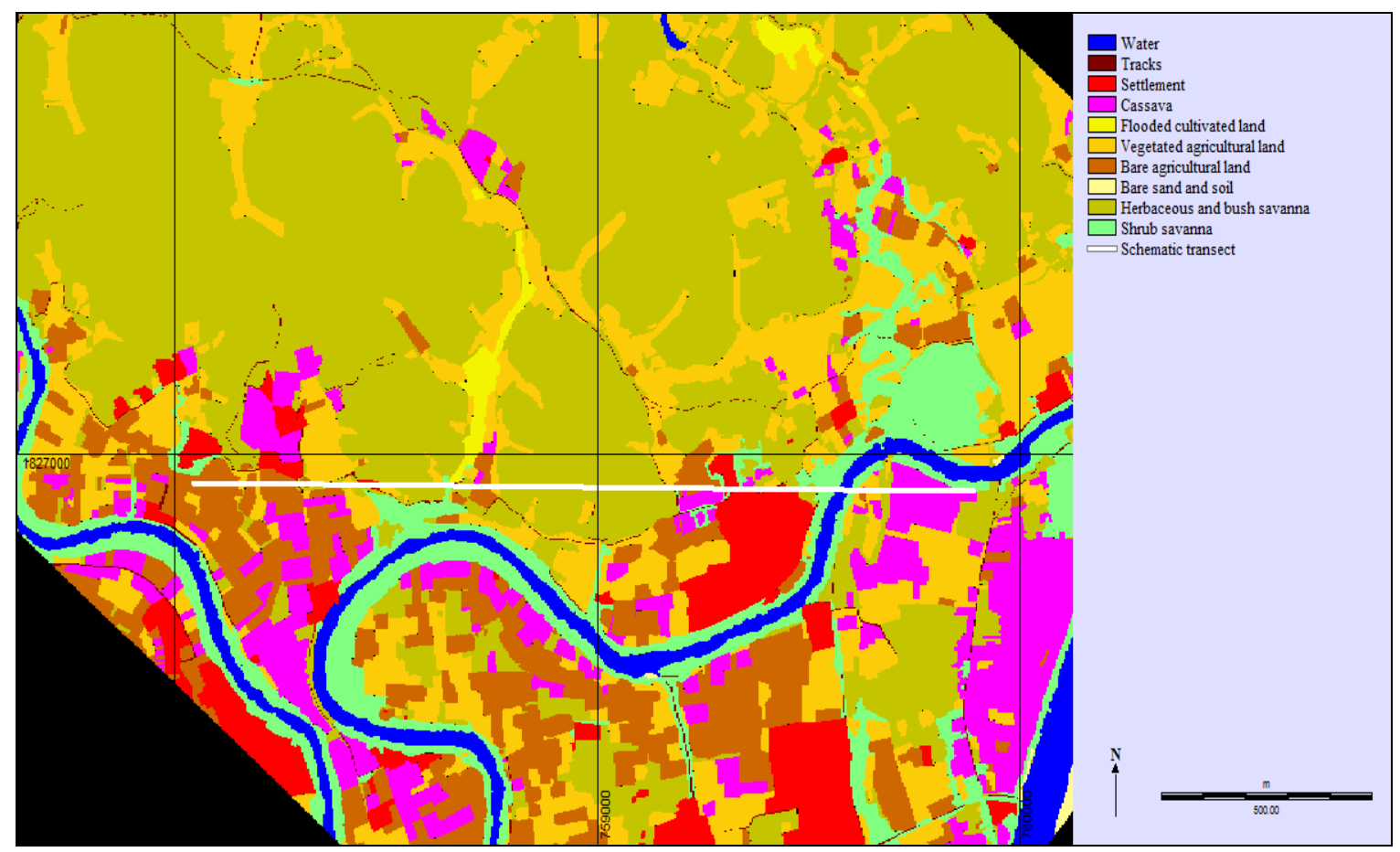

Figure 8. Pre-war landscapes (circa 1954), in the plain - example around Hien Si village.

Source: Aerial photographs from SHD-DAA: Plot 296, Mission TV 310 from 06/20/1953 (1/10,000) (Georeferencing: UTM 48N/WGS 84).

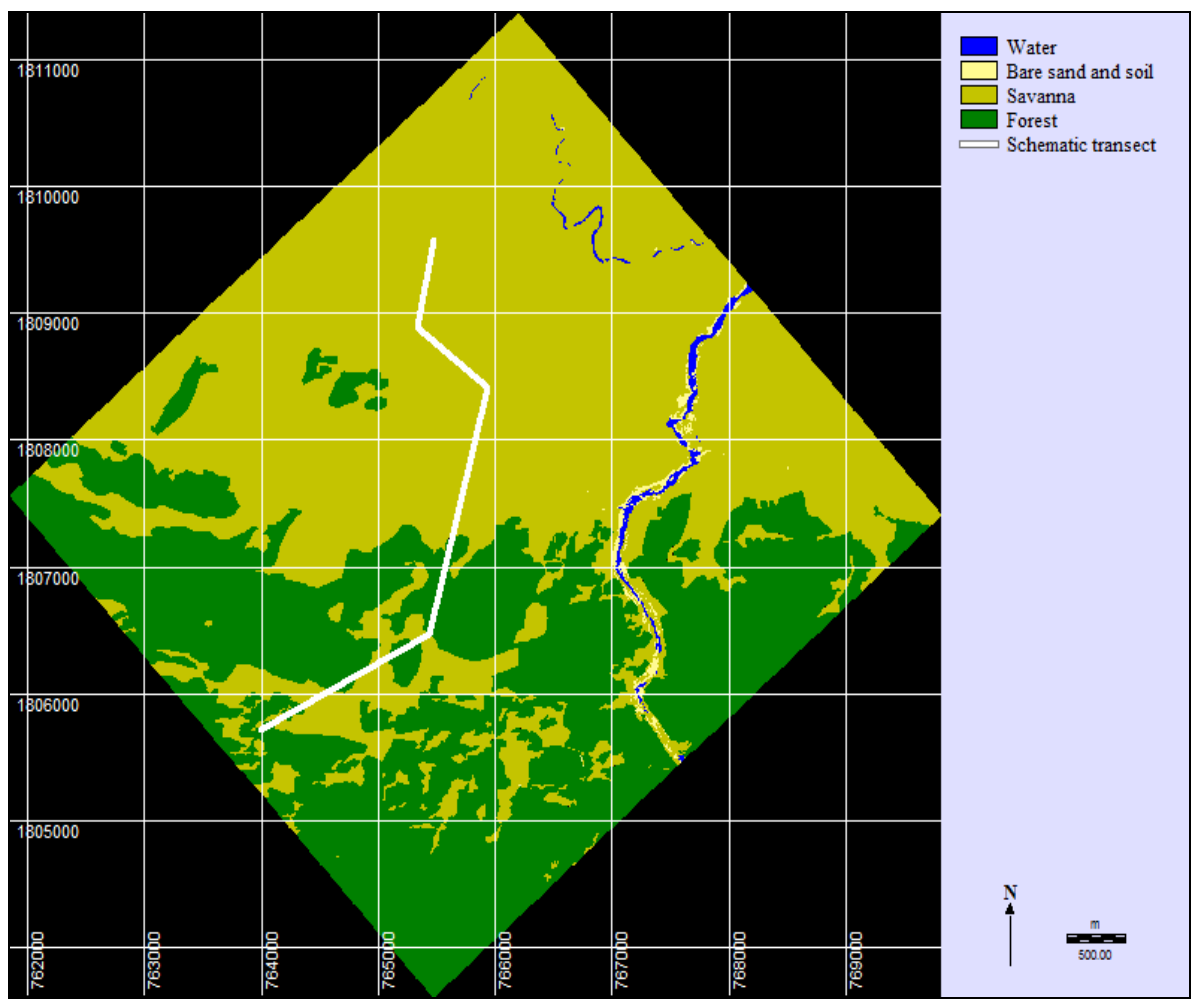

Figure 9. Pre-war landscapes (circa 1954), in the hills - example around Binh Thuan and Binh Loc.

Source: Aerial photographs from SHD-DAA: Plot 745A, Mission TV 65 from 12/18/1953 (1/20,000-1/25,000) (Georeferencing: UTM 48N/WGS 84). 


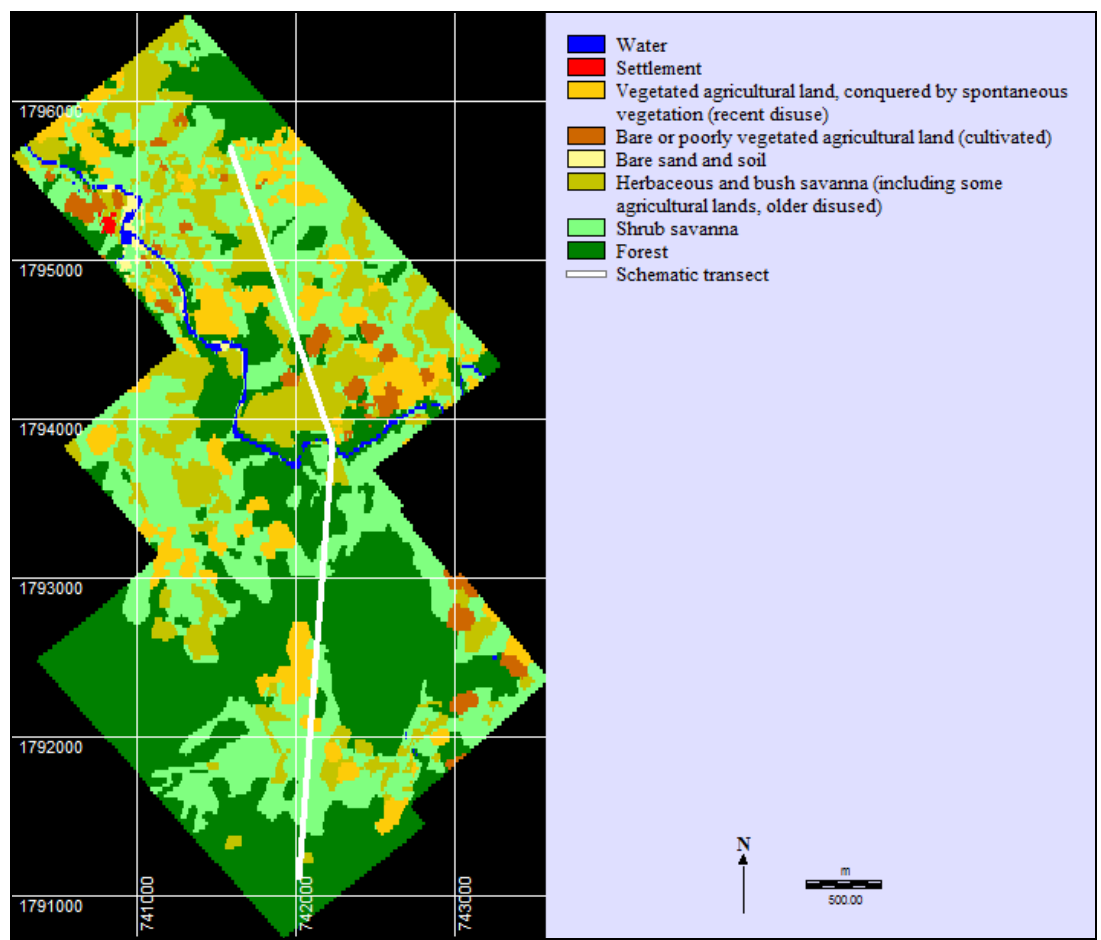

Figure 10. Pre-war landscapes (circa 1954), in the mountains - example around Con Tom (Hong Thuong) village. Source: Aerial photographs from SHD-DAA: Plot 605A, Mission TV 613 from 11/25/1952 (1/7,500) (Georeferencing: UTM 48N/WGS 84).

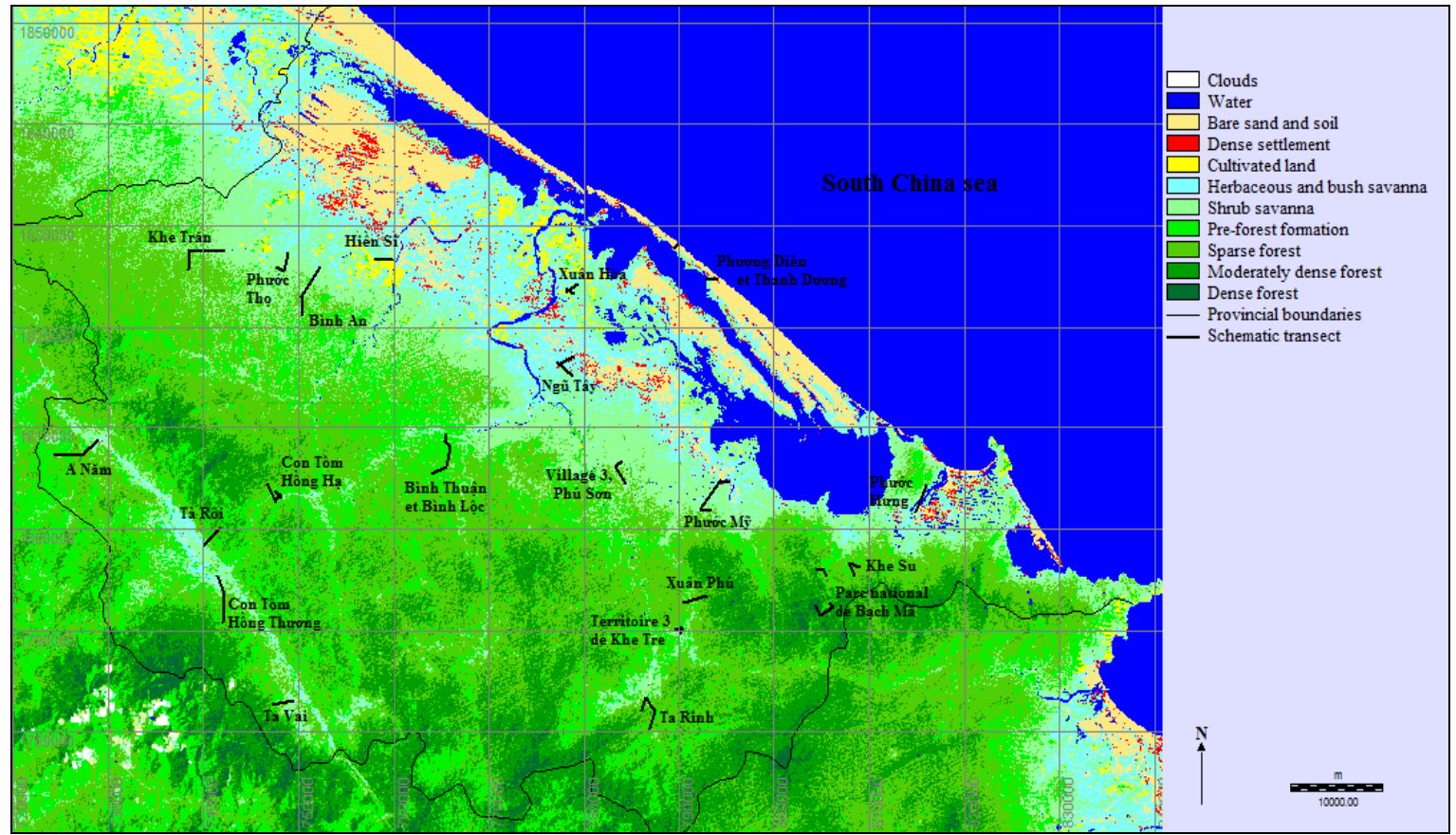

Figure 11. Post-war landscapes (1975), on the province scale.

Source: Landsat 2 MSS image from March 14, 1975 (Georeferencing: UTM 48N/WGS 84).

The knowledge of post-war landscapes was based on another iconographic data, satellite image. The main advantage of this one is the shorter processing than for aerial photographs and the larger covered area: Only one 
image includes the entire studied area. Today, different satellites offer such images but, launched in 1972, Landsat was the only one in service in 1975. The chosen image was thus taken by this satellite.

By comparing these pre- and post-war landscapes, the wartime dynamics could be objectively identified. These iconographic data were the main source but not the only one; they were completed by interviews, which were conducted with villagers. These ones gave precisions about landscapes and their dynamics; they also gave information about the factor of these dynamics. Indeed they were questioned about the military and civilian practices, which may have an impact on landscapes, because the study purpose was to know the dynamics as well to understand these ones, to identify their factors. For that reason, to know the practices, some archives data were studied.

This work was not conducted on the entire area of South-Vietnam; in the Ph.D. framework (Robert, 2011), it focused on Thua Thien Hue province, which was previously presented as an area, which was particularly affected by the military activities during the Vietnam War, due to its location. But, because of the features of the sources - the reconstruction of pre-war landscapes, based on aerial photographs, was only partial, only some transects - among those, which were studied on the ground and are specified on the Figure 7 could be considered for the wartime dynamics. Here, three of them are given as an example. Each one is located in a different landscape unit of the province: Hien Si in the plain, Binh Thuan and Binh Loc in the hills and Con Tom (Hong Thuong) in the mountains (see Figure 7).

\section{Results}

Thanks to the aerial photographs, some maps of land use before the war, around 1954 were drawn on the scale of some transects. With regard to the example of Hien Si area (see Figure 8), the main land use categories in the plain were settlements, agricultural lands and savannas; these ones were located on the nearby hills. In the hilly unit, like on the ground of Binh Thuan and Binh Loc (see Figure 9), the spontaneous vegetation predominated, divided between savanna and forest; the last one covered the higher hills.

In the mountains, some authors like Le Trong Cuc (1983) suggested that the forest was omnipresent. The interviewed villagers gave the same description of the landscapes in the mountains before the war: the forest was everywhere. But the study of the land use map, drawn from the aerial photographs, reveals a reality a little bit different (see Figure 10). The forest covered the slopes but it rarefied in the valley, especially in the A Luoi valley, where is located Con Tom (Hong Thuong) village. The land use became a mosaic, between spontaneous vegetation at different stages and agricultural lands: some of these ones were cultivated at the shooting time but others were disused, lied fallow, since a varied time. This can be explained by the practice of shifting cultivation in this part of Thua Thien Hue province.

According to Figure 11, the land use map could be drawn on the province scale for 1975 . The forest stretched out in the mountainous and hilly areas, whereas the savanna covered the plain and the first hills but also the valley in the mountainous unit.

The comparison with the land use of 1954 requires to be placed on the same scale, on the transect scale. The Hien Si example (see Figure 12), reveals the post-war land use in the plain; it was divided between agriculture and savanna, located in the nearby hills. In the hilly unit, at least on the ground of Binh Thuan and Binh Loc (see Figure 13), the pre-forest formation was the main land use category. In the mountains, this plant formation also stretched out, between savanna in the valley and forest on the higher slopes, with regard to Con Tom (Hong Thuong) area (see Figure 14). 


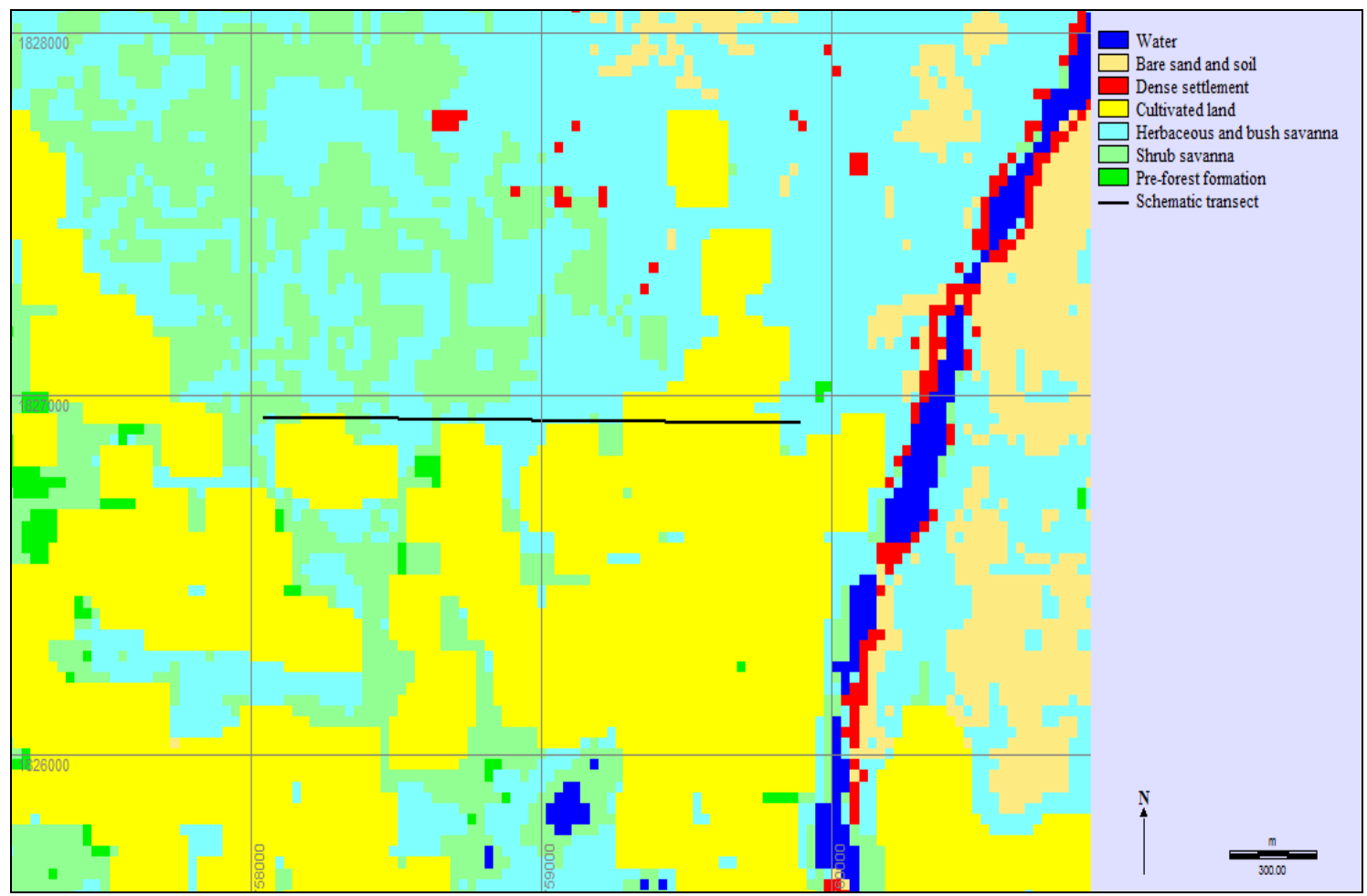

Figure 12. Post-war landscapes (1975), in the plain - example around Hien Si village.

Source: Landsat 2 MSS image from March 14, 1975 (Georeferencing: UTM 48N/WGS 84).

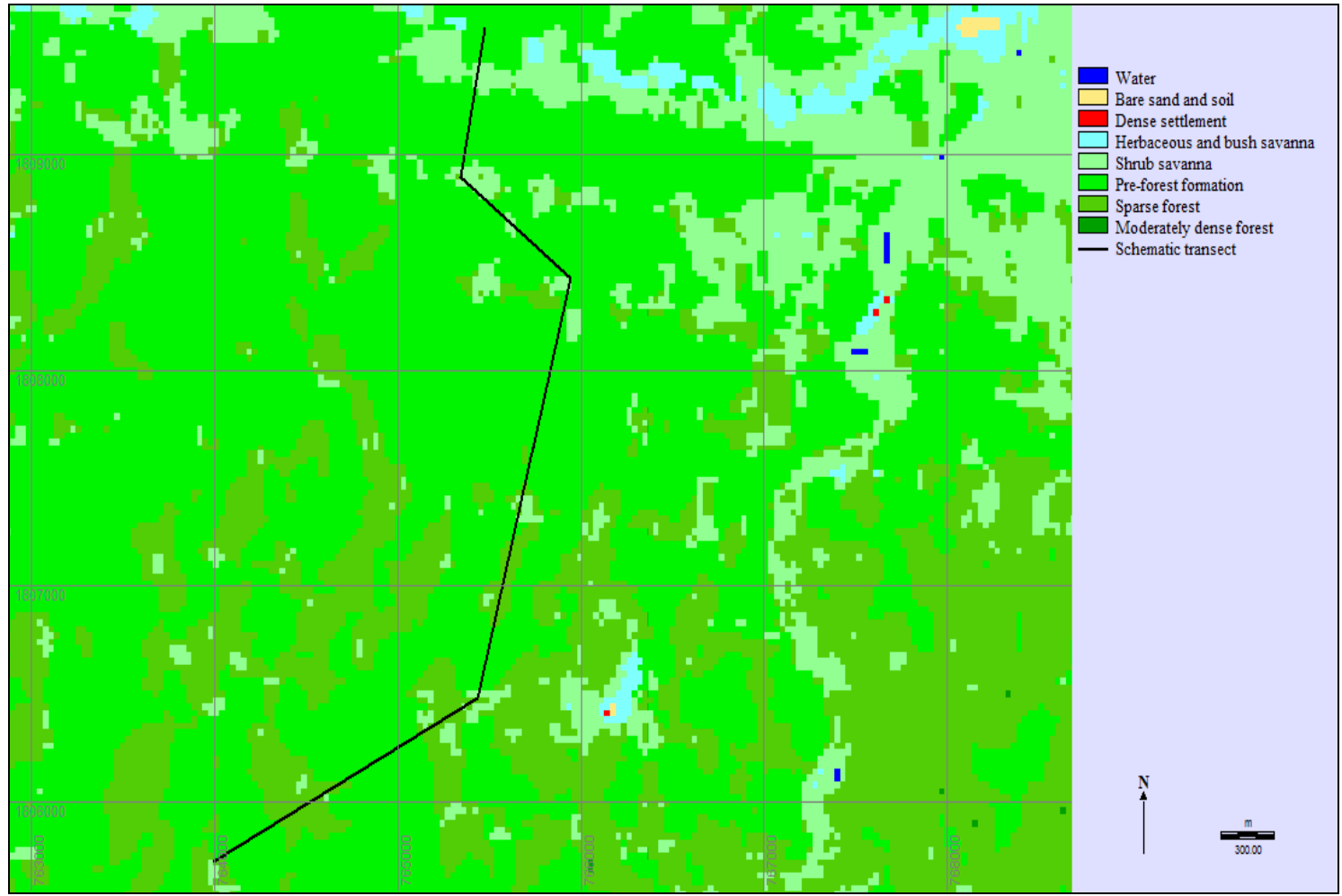

Figure 13. Post-war landscapes (1975), in the hills: Example around Binh Thuan and Binh Loc.

Source: Landsat 2 MSS image from March 14, 1975 (Georeferencing: UTM 48N/WGS 84). 


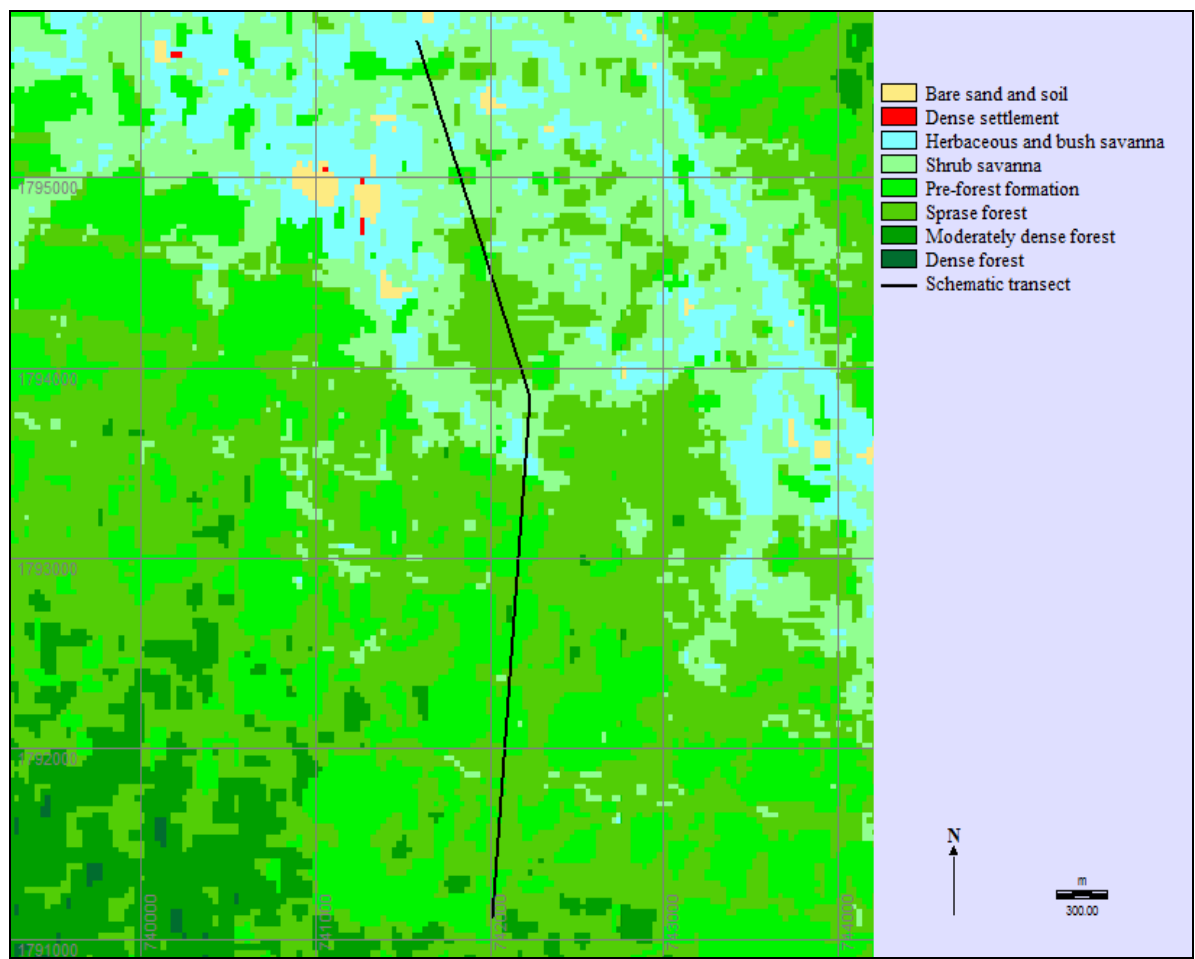

Figure 14. Post-war landscapes (1975), in the mountains - example around Con Tom (Hong Thuong) village. Source: Landsat 2 MSS image from March 14, 1975 (Georeferencing: UTM 48N/WGS 84).

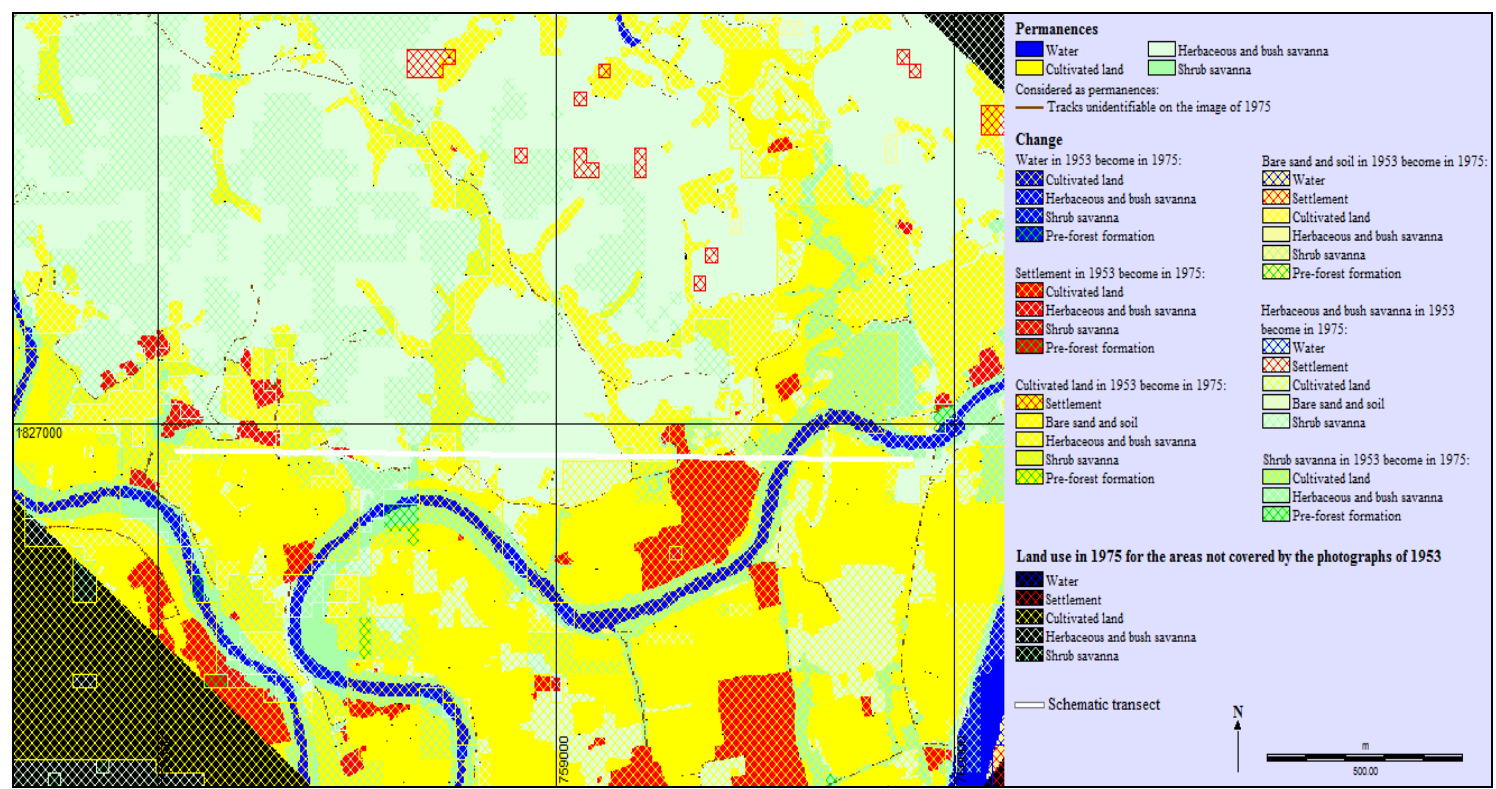

Figure 15. Landscape dynamics during the war, in the plain: Example around Hien Si village.

Source: see Figure 8 and Figure 12.

\section{Discussion: Wartime Landscapes Dynamics and Their Factors}

To identify the wartime dynamics, the maps of 1954 and 1975 were superimposed, although the spatial resolution of both differs; the purpose was to obtain some maps of wartime dynamics, like the ones, which are taken here as example. 


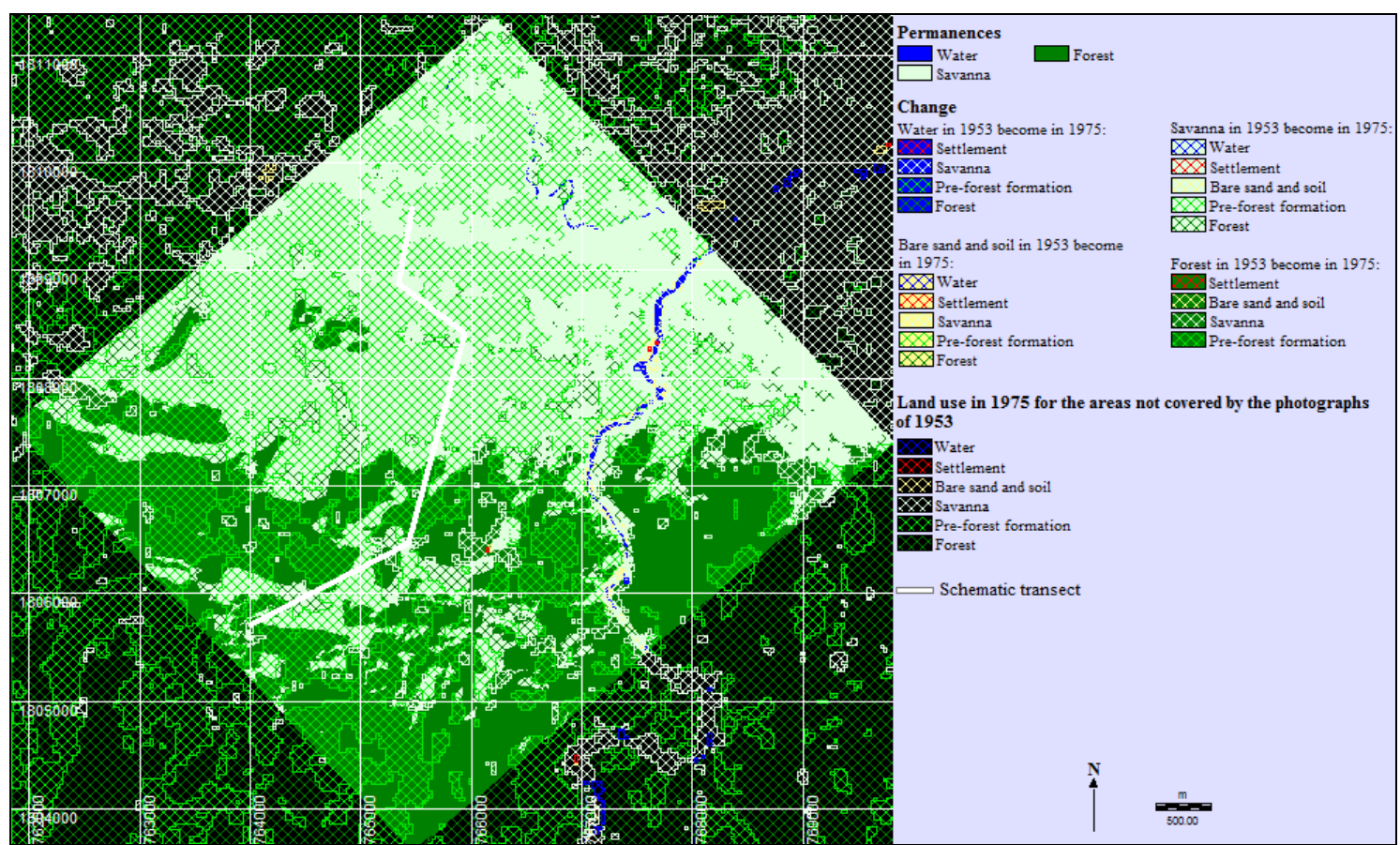

Figure 16. Landscape dynamics during the war, in the hills: Example around Binh Thuan and Binh Loc. Source: see Figure 9 and Figure 13.

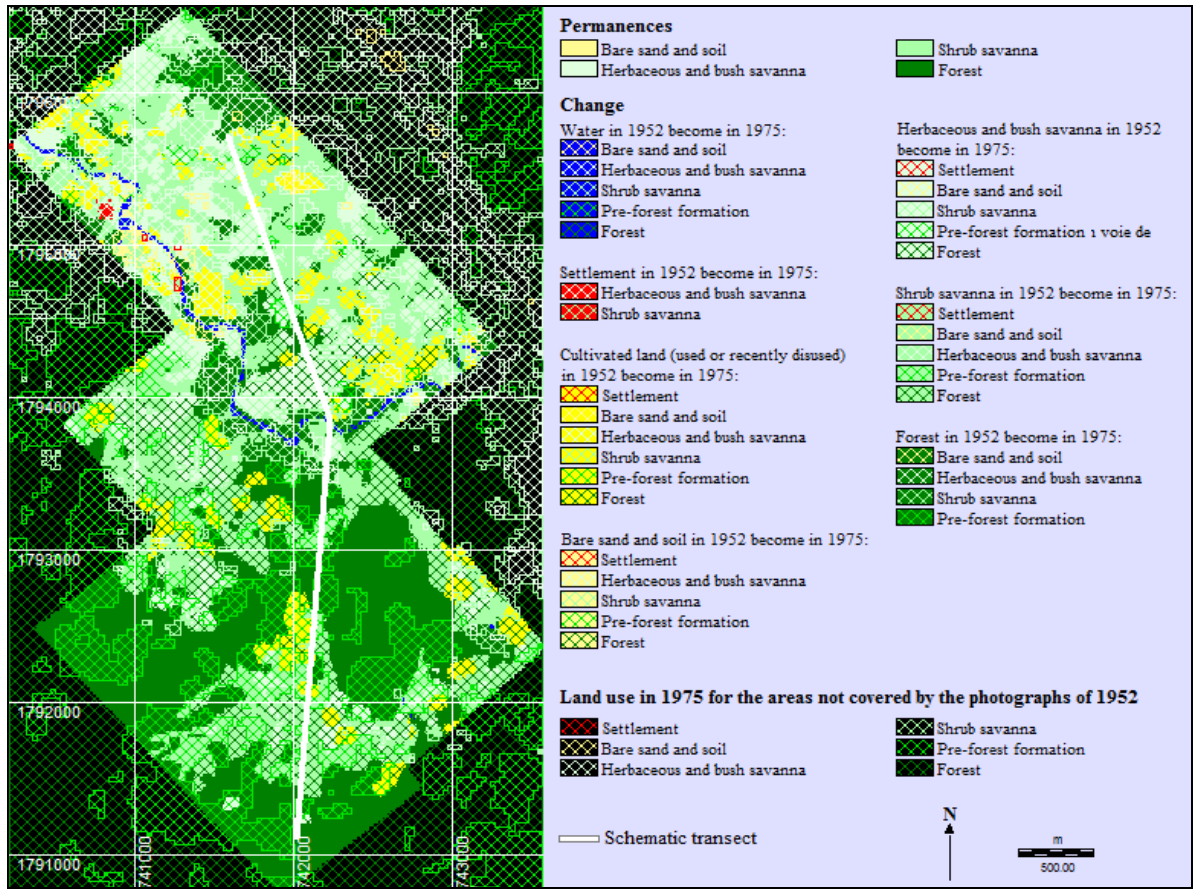

Figure 17. Landscape dynamics during the war, in the mountains: Example around Con Tom (Hong Thuong) village. Source: see Figure 10 and Figure 14.

With regard to Hien Si map (see Figure 15), in the plain, some cultivated lands persisted but others, especially the ones, which were near the hills, disappeared. The houses seemed also to have disappeared. The savannas persisted and moreover spread and progressed from herbaceous stage to shrub one. The accounts of some Hien Si inhabitants allow to understand these dynamics. 


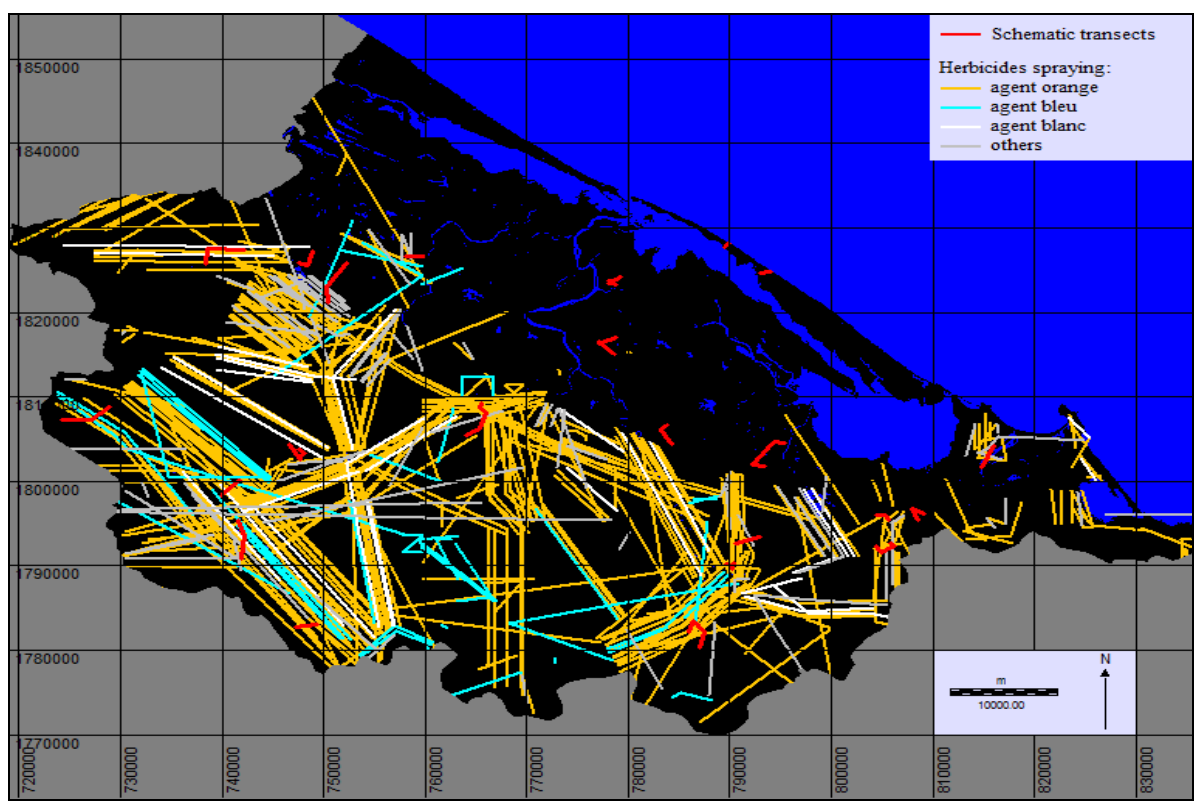

Figure 18. Herbicides spraying in Thua Thien Hue province.

Source: From the map of the Forest Inventory and Planning Institute given by Phung Tuu Boi, drawn from C. SMITH and D. WATKINS (1981). The Vietnam map book, self-help guide to herbicides exposure. Winter Soldier Archive, Berkeley, CA, 107.

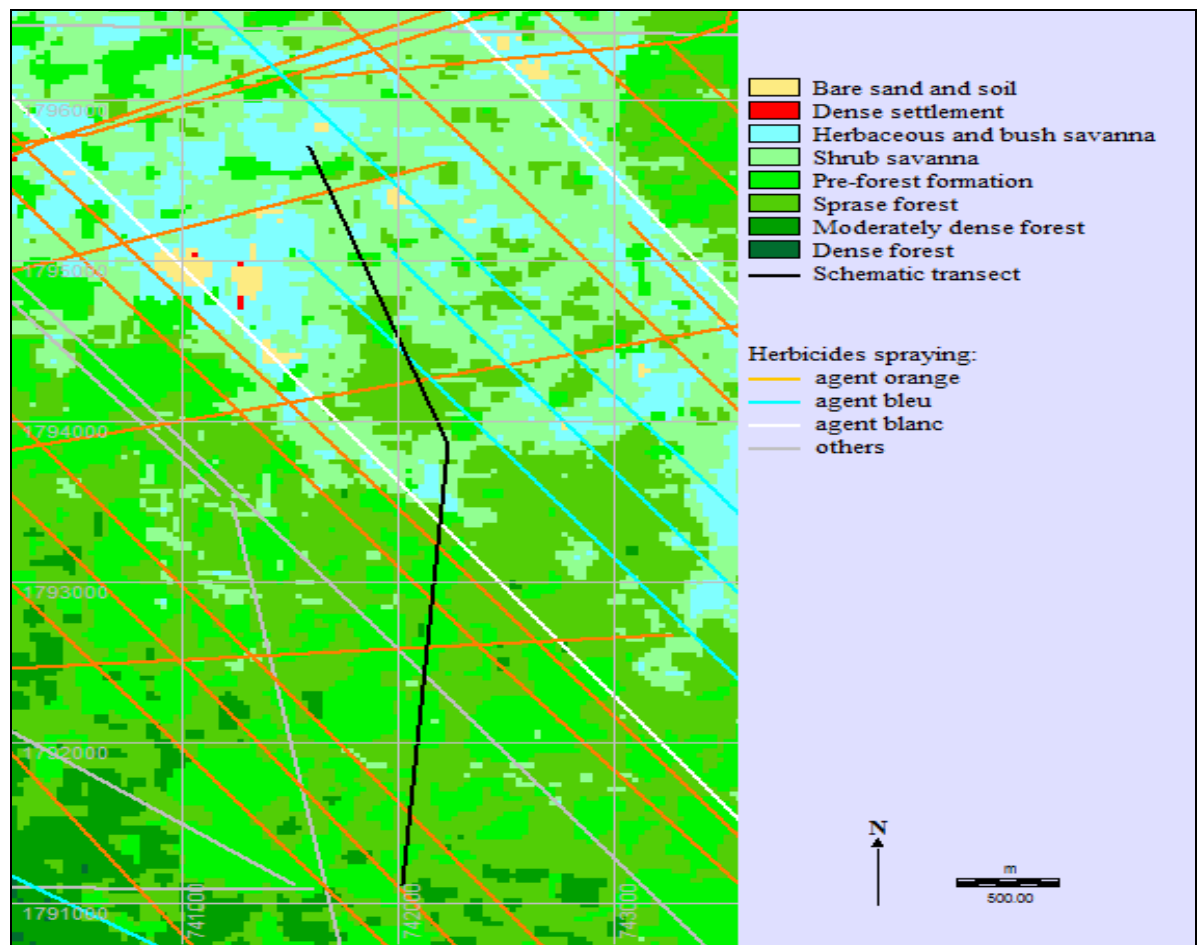

Figure 19. Landscapes in 1975 and herbicides spraying, in the mountains: Example around Con Tom (Hong Thuong) village.

Source: see Figure 14 and Figure 18.

During the war, an American military base was settled on the nearby hills. Around this base, the vegetation was regularly destroyed but, more fare, the savanna could progress because the villagers stopped to 
collect firewood. They even left their village to another one, safer. The houses and the cultivated lands were abandoned. In 1975, at the date of the image, the fighting stopped and the villagers already returned in their village. A part of the agricultural lands was again cultivated.

In the hills, as the Figure 16 proves it, two main dynamics could be observed. One was a progress from savanna to pre-forest formation; the other was a regression from forest to pre-forest formation. This part of the province was almost inhabited before and during the war; consequently, no villager account can be obtained. But thanks to the study of some archives data, these dynamics can be explained. The slopes were most affected by the military practices, most concerned by the military presence whereas, in the valley, the civilian practices, consisting in particular in forest exploitation, stopped when the fighting began. Here the vegetation was only destroyed near the road, that were taken by the soldiers, explaining the persistence of the savanna around this axis (at the north end of the transect) (see Figure 16).

In the mountains, the dynamics which are revealed by Con Tom (Hong Thuong) are more varied (see Figure 17). The cultivated lands disappeared; the savanna persisted in the valley and even progressed. On the first slopes, the progress from savanna to forest could be observed; but this can be questioned according to the time necessary for this change. By contrast, on the higher and father slopes, the forest sometimes regressed to pre-forest stage. The interviews conducted with the villagers enlightened these dynamics. The villages, which were located in the valley, were deserted during the war; houses and agricultural lands were left to the spontaneous vegetation. The dynamic was thus a progress; the deserted areas were reconquested by the grass, then the shrub and in 1975 a shrub savanna could be observed. But the vegetation on other areas knew an inverse dynamic. Indeed, they were affected by the military activities, especially by herbicides spraying. The province was heavily sprayed by herbicides (see Figure 18); the spraying localization is known and thus the map could be superimposed on the maps of landscape dynamics, to know the consequences of herbicides spraying. The example, which is chosen here, around Con Tom (Hong Thuong) village, is taken in the main targeted area, the A Luoi valley, in the mountains - here was a part of the Ho Chi Minh trail. To make the reading of the map easier, herbicides spraying are only superimposed on the local map of land use in 1975 (see Figure 19). This work proves that, following herbicides spraying, the forest could persist. All sprayed areas were not covered by savanna after spraying, as all sprayed areas were not covered by the forest before spraying.

\section{Conclusion}

The forest was not omnipresent before the war in the mountainous area, as some authors assert and, after the war, the savanna was not so predominant, except in the valley. The war consequences have to be put into this perspective.

Moreover, the landscape dynamics during the war were not only regressions; some progresses could be observed. Indeed, the military practices were not the only factor of dynamics. The civilian practices changed during the war; they had also an impact on the landscapes and this impact changed. The desertion of some villages explains that the dynamics could be a progress.

Herbicides spraying had immediate consequences on the vegetation but they didn't conduct systematically to forest loss. Only a percentage of the trees died following one spraying, knowing that some affected areas were not covered by the forest. When herbicides spraying were repeated on the same forest areas, they led to forest destruction. Thus these spraying, more generally the military activities, contributed to forest decline but they're not the main reason of deforestation. The decline of the forest speeded up in the post-war period; other 
causes are then identified: forest exploitation, increasing of agricultural lands... (Robert, 2011). Beyond the deforestation, herbicides spraying had other consequences; the dioxin, which was contained in some of these products, contaminated environment (soils, water, fauna and flora), food chain and men (Robert, 2011; Hatfield Consultants LTD and 10-80 Committee, 1998; Dwernychuk, 2005). This consequence is still a major problem today, especially in the hot spots which are the former military bases (Robert, 2011; Hatfield Consultants LTD and 10-80 Committee, 1998; Dwernychuk, 2005).

\section{References}

Collins, M. (1990). The last rain forests, a world conservation atlas. New York: Oxford University Press,.

de Koninck, R. (1999). Deforestation in Viet Nam. International Development Research Centre, Ottawa.

Dwernychuk, L. W. (2005). Short communication dioxin hot spots in Vietnam. Chemosphere, 60, 998-999.

Hatfield Consultants LTD and 10-80 Committee. (1998). Preliminary assessment of environmental impacts related to spraying of Agent Orange herbicide during the Viet Nam war. Retrieved from http://www.hatfieldgroup.com/wp-content/uploads/AgentOrangeReports/CIDA614/default.htm

Le Trong Cuc. (1983). «Les effets durables de la guerre chimique sur l'environnement du district [d']A Luoi—province [de] Binh Tri Thien » [The lasting effects of chemical warfare on the environment of A Luoi district-Binh Tri Thien province], dans Comité national d'investigation des conséquences de la guerre chimique américaine au Viêt Nam [National committee of investigation on the consequences of the American chemical warfare in Viet Nam], 1983, Symposium international sur «les herbicides et défoliants employés dans la guerre : les effets à long terme sur l'homme et la nature »[International symposium on "herbicides and defoliants used during the war: the long-term effects on man and nature"] (Ho Chi Minh-City, January 13-20, 1983), vol. II, Hanoi, pp. 137-139.

Robert, A. (2011). Dynamiques paysagères et guerre dans la province de Thừa Thiên Huế (Việt Nam central), 1954-2007-Entre défoliation, déforestation et reconquêtes végétales (Landscape dynamics and war in Thừa Thiên Huế province (Central Việt Nam), 1954-2007-Between defoliation, deforestation and reforestation). Ph.D. Thesis, defended the December 3rd, under the direction of Professor J. P. AMAT, Paris-Sorbonne University, 1172 p. + Atlas.

San, N. V., \& Gilmour, D. (1999). Forest rehabilitation policy and practice in Vietnam. IUCN-The World Conservation Union.

Stellman, J. M., Weber, S. D. T., Tomasallo, C., Stellman, A. B., \& Christian, R. (2003). A geographic information system for characterizing exposure to agent orange and other herbicides in Vietnam. Environmental Health Perspectives, 11(3), 321-328.

Westing, A. H. (1972). Herbicides in war: Current status and future doubt. Biological Conservation, 4(5), 322-327.

Westing, A. H. (2002). Assault on the environment. In A. H. Westing et al. (Eds.), Long-term consequences of the Vietnam Warecosystems. Report to the environmental conference on Cambodia, Laos, Vietnam (July 26-28), Föreningen Levande Framtid, Sweden. 